\title{
BRIDGES AND BARRIERS IN PUBLIC SERVICE INTERPRETING TRAINING: INSTRUCTING NON-PROFESSIONAL LONGSERVING INTERPRETERS ${ }^{1}$ / PUENTES Y BARRERAS EN LA FORMACIÓN EN INTERPRETACIÓN EN LOS SERVICIOS PÚBLICOS: LA DOCENCIA A INTÉRPRETES CON EXPERIENCIA NO PROFESIONAL
}

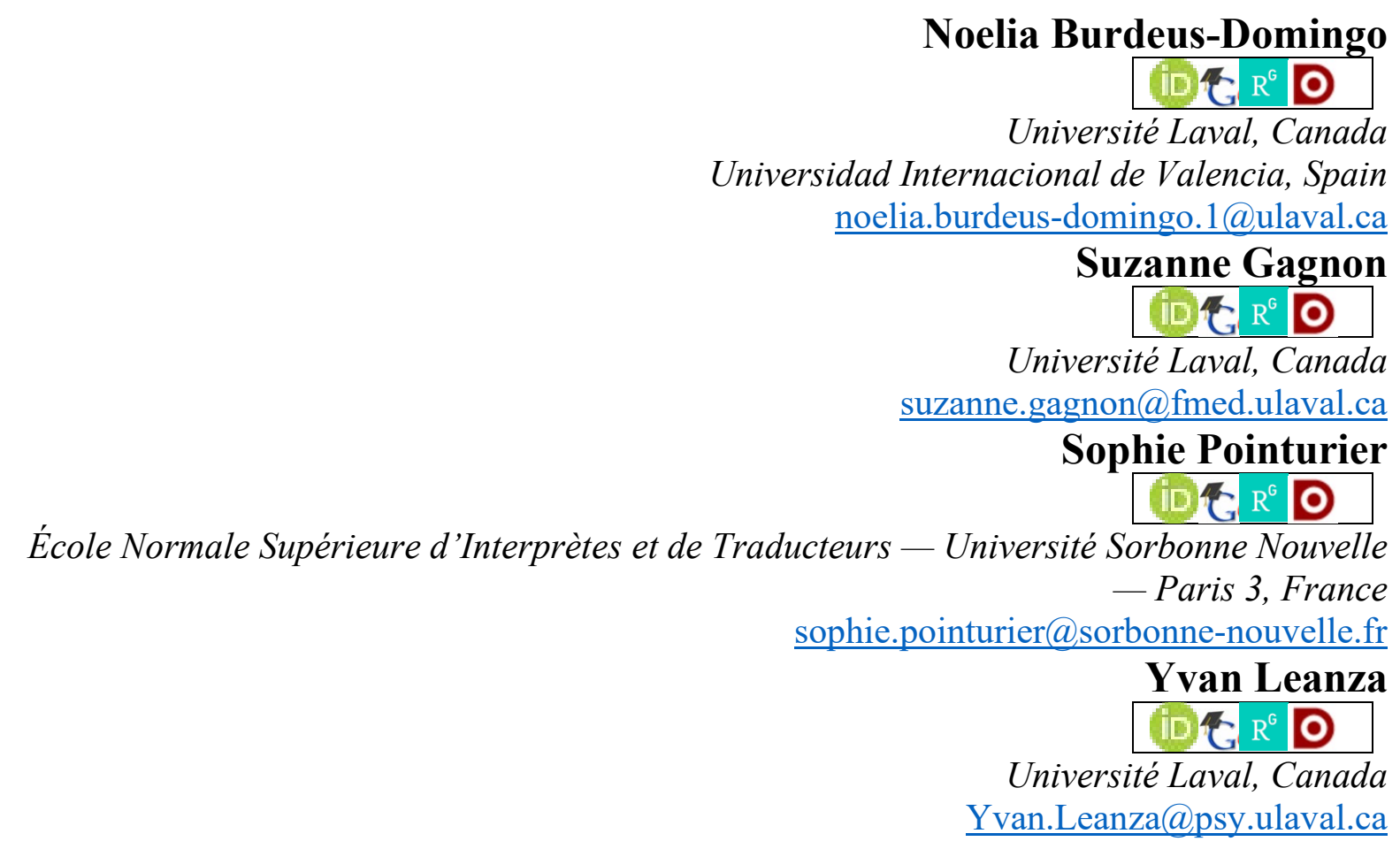

\begin{abstract}
This paper reports on an action-research study with a dual purpose: (1) to design a PSI training programme adapted to the needs of the City of Québec's public healthcare institutions, and (2) to assess its contribution to the development of trainees' PSI competences. The course was designed adapting ÉSIT's special regime methodology to PSI training, and delivered to a group of non-professional interpreters $(\mathrm{N}=23)$. The evaluation was undertaken qualitatively, through two focus groups $(\mathrm{n}=11)$. The data collected was submitted to content analysis and contrasted with the trainer's action-research report. Findings reveal (1) that the special regime methodology can be applied to PSI training programmes, if combined with pedagogical approaches adjusting it to the group's needs, and (2) that trainees' preconceptions about PSI add up to the list of challenges of
\end{abstract}

\footnotetext{
${ }^{1}$ The research leading to this paper was undertaken thanks to the funding obtained with an ARGO grant, from the Spanish Ministry of Education, Culture and Sports.
} 
training non-professional longserving interpreters. Our concluding remarks present several recommendations on how to overcome the detected difficulties.

Keywords: Public Service Interpreting, training, non-professional interpreters, special regime

Resumen: Este artículo da cuenta de un estudio de investigación-acción con doble objetivo: (1) diseñar un programa de formación en ISP adaptado a las necesidades de las instituciones sanitarias públicas de la ciudad de Quebec y (2) evaluar su contribución al desarrollo de las competencias necesarias para la ISP. El curso, que adapta la metodología del régimen especial de la ÉSIT a la formación en ISP, se impartió a un grupo de intérpretes no profesionales $(\mathrm{N}=23)$ y se evaluó cualitativamente mediante dos grupos focales $(n=11)$. Los datos recopilados se sometieron a un análisis de contenido y se contrastaron con el informe de investigación-acción de la formadora. Los resultados revelan que (1) la metodología de régimen especial puede aplicarse a la formación en ISP, si se combina con enfoques pedagógicos que la ajusten a las necesidades del grupo, y (2) las ideas preconcebidas sobre la ISP se suman a la lista de retos que supone instruir a intérpretes con experiencia no profesional. A modo de conclusión, presentamos una serie de sugerencias para superar las dificultades detectadas.

Palabras clave: Interpretación en los servicios públicos, formación, intérpretes no profesionales, régimen especial

\section{Introduction}

Public Service Interpreting (from now on PSI) is the result of a social need that is common to any multicultural society, where multilingualism prevails in all areas. When one or more groups do not master the predominant language, the need for language services becomes apparent. Without them, many society members would never succeed to communicate within the public sector, finding difficulties to access public services.

Even though societies' multilingualism is probably as old as humanity itself, only some states under the rule of law, such as Canada, have passed laws to impose on their institutions the duty of welcoming such linguistic diversity (Leanza et al., 2017). As Jiménez Salcedo (2014) points out, the Canadian Administration acknowledges multiculturalism and multilingualism as features that characterise the Canadian society. Accordingly, it recognises both linguistic rights and rights of access to public services. The former - based on the principle of equality of national communities - enable Canadians to access public services in their official language of preference (English or French), regardless of the priority language of the geographical context in which they are located. The latter - based on the principle of equity - allow allophones to access public services in their mother tongue, thanks to the intervention of an interpreter. Nevertheless, Canadian PSI services have not become widespread at the federal level, but rather at the regional and provincial levels (Ozolins, 2000; Valero-Garcés, 2003; Burdeus-Domingo, 2015), which has originated different services, with different approaches, and a consequent lack of homogeneity and coordination between them.

\section{Quebec's interpreters bank model}

Quebec's cultural diversity management policies and practices follow an integration model centred on communication (Auger, 2005). As a consequence, the province has set up PSI services in the form of banks of interpreters (Jimenez-Salcedo, 2010, 2014; Burdeus-Domingo, $2015,2019)$, the use of which is perceived as a right for linguistic minorities. Interpreters registered to such banks provide PSI services to the different levels of the public administration, for which banks bill institutions (Burdeus-Domingo, 2015, 2019). 
The City of Québec is no exception to such trend. Each year, it receives hundreds of refugees as part of the provincial immigration regionalisation policy. It also welcomes a large number of new permanent residents, temporary workers and foreign students. Thus, in recent decades, its population has been considerably diversified in terms of the origin of its members and the languages spoken (CIUSSS-CN, 2019), which implies an adaptation of public services. After the arrival of Syrian refugees in 2015, the healthcare authorities of the City of Québec decided to improve the provision of their PSI services by creating the Banque d'Interprètes de la Capitale Nationale (BICN). This was fostered by the results of several studies conducted within the province's healthcare network, which highlighted both the shortcomings of the services provided to allophones and the frustration among healthcare professionals (Leanza, 2017; Leanza et al., 2010).

A particularity of the situation in the City of Québec is the difficulty to find potential interpreters with a sufficient level of French proficiency and some understanding of Quebec's healthcare system. This is due to the fact that the population available in the region to potentially act as a link in communication is the allophone population itself, composed mainly of new migrants, who frequenlty lack of a high level of French. This led the BICN to offer language services, ever since its creation, with untrained interpreters of different cultural and educational backgrounds - often with a lack of certain knowledge and skills that are necessary to perform interpreting and intercultural communication tasks.

\section{Public Service Interpreting training}

Hale (2007) reveals that training is one of the most problematic aspects of PSI, due to the lack of recognition of the need for training in this area, the absence of training requirements prior to the practice of PSI, the scarcity of adequate training programmes and the quality and effectiveness of existing training. Pöchhacker (2004) relates this shortage of training to the lack of funding for PSI practice. Thus, while some academic institutions offer formal PSI training (either at the vocational or university level), many non-academic institutions offer their own non-formal training (Abril Martí, 2006; Burdeus-Domingo, 2010, 2015; Mikkelson, 2014).

In general, in the academic field, interpreting courses tend to meet the needs of limited language pairs (Abril Martí, 2006). They are usually addressed to Translation and Interpreting students, who are aware of the challenges imposed by language practices and have a common educational background. These training options present objective content, which is based on what research has shown to bring benefits to the practice of PSI.

When talking about academic training, it should be noted that, unlike in Europe, not all Canadian Translation university departments offer the possibility of in-depth interpreting training. Some only offer general introduction to interpreting courses (regardless of the context or interpreting modality), which makes it difficult in many provinces to find language professionals who are qualified to carry out complex interpreting tasks. Moreover, even though seldom Translation university programmes offer courses on translation from other languages (mostly Spanish), the English-French language combination is the predominant one, which leaves behind the language combinations required in the field of public services (i.e. newcomers' mother tongues or even indigenous languages).

With regard to PSI training in Canada, the Language Industry Association (AILIA) promotes a post-secondary level training model with four levels of training. The first level includes 180 hours of training, practical interpreting tests, an English proficiency test and 200 hours of documented interpreting practice. The last level is designed to train interpreters who specialise in medical, legal or social interpreting; and consists of 1500 hours of documented interpreting practice and 120 hours of medical, legal or social training. According to the AILIA 
website, only a few centres in Ontario offer this type of training. It is therefore not surprising that non-academic PSI training is predominant throughout the country, whether it comes from the public services where interpreters work — with trainers from different fields, such as medicine or psychology - or from trainers that are specialised in interpreting, who are often hired on an ad hoc basis to provide tailored training on demand (Abril Martí, 2006). This trend is followed in the province of Quebec, where, despite the efforts of some academic institutions to regulate PSI training (Burdeus-Domingo, 2015), it is mainly public service institutions or immigrant associations that are responsible for training their interpreters. These are, for the most part, short courses that serve to meet specific needs and are often conditioned by the institution's interests — whether these are economic, political, etc.- (Vargas-Urpí, 2013). Along these lines, the BICN provides its newly recruited interpreters with an initial seven-hour workshop - delivered by an Interpreting scholar - that allows them to broadly outline the interpreters' duties at the bank.

\section{The study}

In the following pages, a study aimed at creating, teaching and evaluating the pilot version of a basic PSI training course for non-professional interpreters working at the BICN is presented. It covers both research and PSI training tasks and is part of the PSI research programme of the Psychology and Cultures research laboratory of the School of Psychology at Université Laval (Québec).

Our laboratory, which participated in the integration of PSI services in the City of Québec's refugee healthcare clinic, works with the city's healthcare authorities to improve PSI services through training actions. In 2017, given the difficulty to find trained healthcare interpreters in Quebec - especially for those languages considered rare, due to their small number of speakers so far-, the BICN asked us to undertake the present project, in order to optimise the training of its interpreters, who had so far received no training beyond the mentioned initial workshop. Based on this request, the following general objective was set: to design, teach and evaluate specialised PSI training, considering the needs of Quebec's interpreters banks (in general), and more specifically those of the BICN. Since the BICN is hierarchically dependent on the Centre intégré universitaire de santé et de services sociaux de la Capitale-Nationale, a public body of the Quebec Ministry of Health, and although its interpreters occasionally cover assignments for public services of all kinds, the proposed training focused mainly on PSI in the healthcare field, at the express request of the BICN's managers.

To achieve this objective, the resulting training had to meet the following conditions:

- be open to all types of trainees, regardless of their level of education, given the profile of potential BICN interpreters; and

- offer training apt to prepare professionals in several languages: with a particular focus on Quebec's languages of immigration, bearing in mind that these vary over time, depending on the fluctuations of migration.

Like previous studies carried out by the members of the Psychology and Cultures laboratory, the present project follows an action-research methodology, which was consecrated by Lewin (1944) in order to link the experimental approach proper to social sciences with the social action programmes that arise in response to social problems. This methodology has been widely applied to teaching and, more recently, to research in translation and interpreting training (Hubscher-Davidson, 2008; Hanna, 2009; Takeda, 2010; Boéri and de Manuel Jerez, 2011; Risku, 2016; Haro-Soler and Kiraly, 2019; Rodríguez de Céspedes, 2020). Its application made it possible to interpret the dynamics that were established in the classroom from the point 
of view of the actors themselves (researcher/trainer and trainees). ${ }^{2}$ Based on Elliot's (2000) action-research description, this experience was analysed bearing in mind the conditions in which this project was developed. Thus, this study considered (1) trainees' understanding of PSI, (2) their beliefs about this practice, (3) their expectations regarding the training programme and (4) their attitudes in the teaching-learning process. It was based both on the collection of first-hand data from trainees - through focus groups - and on the participant observation of the trainer, who was part of the research team.

The project was developed during the academic year 2017-2018 and consisted of the following phases: (1) training needs assessment, undertaken jointly with the BICN's representatives, (2) review of existing literature on PSI training, (3) training programme design, (4) training delivery and (5) training evaluation.

\subsection{Training needs assessment}

During the initial phase of this project, the researchers met with the BICN representatives to assess the training needs that they had been observing ever since the creation of the bank. During these meetings, a consensus was reached on what was understood by PSI and on the good practices to promote through the training programme. It was thus agreed to promote the practice of PSI as described by research in interpreting studies (Pöchhacker, 2004). All things considered, it was agreed that the training programme would be created by considering PSI as a professional activity that requires

- expert knowledge and skills made up of the different sub-competencies that constitute the translation competence, as well as

- specific knowledge from different fields - intercultural communication, translation and interpretation, documentation, organisation and operation of public services, etc.

\subsection{Literature review on PSI training}

The pilot training programme was designed based on an analysis of both the structure and the content of existing PSI training programmes, as well as on the specific needs of the city of Québec's migratory reality. According to Industry Canada (2007), even though the duration of PSI professional training in Canada is heterogeneous, the average programme length is approximately 180 hours. The most common training programmes, however, consist of intensive courses of about 40 hours, that are offered by public institutions (Abril Martí, 2006). We intended to respect these trends and created an 80-hour course, composed of 48 teaching hours and 32 hours of practice at the BICN. The content of the PSI basic training programme was selected considering Abril Martí and Martin's (2008) application to PSI of Kelly's translation competence model (2005) and according to the specific quality standards for PSI in Canada described by the Healthcare Interpretation Network (2007).

\subsection{Training programme design}

\subsubsection{Training objectives}

The main objective of the training programme was to develop the theoretical knowledge, skills and reflexes that are needed for the performance of PSI, based on a theoretical and practical approach. Hence, priority was given to expose trainees to diverse PSI situations and tasks -

\footnotetext{
2 The researcher in charge to implement the training programme was the first author of this paper. She holds a $\mathrm{PhD}$ in Translation and Intercultural Studies, specialized in interpreting, and has a wide teaching and research experience in the field.
} 
including simultaneous interpreting, consecutive interpreting, liaison interpreting, sight translation, etc. - in order to prepare them to successfully serve as linguistic and cultural links between public service workers and non-French-speaking users. With this general objective in mind, the following specific goals were set:

1. to foster understanding of PSI as a professional task;

2. to promote trainees' understanding of the interpreting reality;

3. to introduce trainees to the basic theoretical, methodological and practical foundations of the discipline; and

4. to strengthen trainees' capacity for critical thinking and develop their reflection on PSI ethics.

\subsubsection{Pedagogical approach}

Bearing in mind that the training programme had to foster knowledge acquisition in a heterogeneous group of trainees, regardless of their level of education, it was designed following a cognitive learning approach (Gredler, 1997), focused on information processing. According to Gredler (1997), prior knowledge is central to such learning approach, as learning is seen as the organisation of new and prior knowledge and the processes involved in perceiving, understanding and storing information. This was considered the ideal approach to introduce new knowledge to non-professional interpreters that had already had some experience in the field of public services, as their common knowledge and experience could be not only taken into account but also valued in the process of competence development. Following the current teaching trends, the course was designed using a participatory pedagogy and an action-oriented task-based teaching methodology, grounded in meaningful, collaborative and reflective learning processes. Its lessons alternated theoretical presentations and practical (group) problem-solving activities, similar to those that trainees were facing in their everyday activities as interpreters of the BICN.

The practical activities were designed following the special regime teaching methodology developed by the École Supérieure d'Interprètes et Traducteurs de l'Université Sorbonne Nouvelle - Paris 3 (ESIT), based on the principles of the Interpretative Theory of Translation (Roux-Faucard, 2005). In this methodology, the trainer plays the role of a "naive researcher', since, as he or she does not understand one of the languages, he or she relies on the information provided by the students to evaluate the quality of their performance and the sequencing of ideas, questioning them according to the principles of mayeutics (Détienne, 2011). Along these lines, the implication of trainees is essential for the development of the training programme, as they are involved in training activities since their planning phase (Roux-Faucard, 2005; Détienne, 2011). The trainer took on the role of mediator - leaving behind that one of knowledge provider-, limiting herself to facilitating the appropriation of the necessary instruments for trainees to build their own learning as they advanced through the training programme. This methodology enhanced cognitive learning by promoting trainees' reflection on practice and awareness raising on PSI-related contents. It also helped by making trainees the centre of the training programme. The aim was for learning to take place as a social activity, in which trainees would not only learn only from the trainer, but also from their interaction with fellow trainees.

\subsubsection{Contents and structure}

Based on the accommodation to PSI of Kelly's translation competence model (Kelly, 2005) undertaken by Abril Martí and Martin (2008), the PSI basic training was divided into 5 modules, designed to facilitate the development of the seven sub-competences that make up the translation competence. Table 1 (below) outlines the competencies that are addressed in each module: 


\begin{tabular}{|l|l|}
\hline \multicolumn{1}{|c|}{ Module } & \multicolumn{1}{|c|}{ Sub-competence } \\
\hline 1. Introduction to PSI and intercultural communication & $\begin{array}{l}\text { Professional and instrumental } \\
\text { Cultural and intercultural }\end{array}$ \\
\hline 2. Initiation to interpreting techniques & $\begin{array}{l}\text { Professional and instrumental } \\
\text { Communicative and textual } \\
\text { Psycho-physiological } \\
\text { Strategic } \\
\text { Interpersonal }\end{array}$ \\
\hline 3. Critical thinking on ethics and guided practice & Professional and instrumental \\
\hline $\begin{array}{l}\text { 4. Tools and resources: terminology and documentation for } \\
\text { healthcare interpreters }\end{array}$ & Thematic \\
\hline 5. Immigration, culture and healthcare system & Thematic \\
\hline
\end{tabular}

Table 1. PSI basic training programme's contents and structure. Source: Own elaboration.

\subsection{Training delivery}

\subsubsection{Duration}

The course was taught on-site, between November 2017 and March 2018. The 16 weekly 3hour lessons were held at the Jeffrey Hale Hospital (Québec), the institution that houses the BICN's headquarters.

\subsubsection{Participants}

A total of $23 \mathrm{BICN}$ interpreters were involved in this study. Their language combinations involved French and 28 other languages, including languages considered rare in Quebec because of their number of speakers within the province, such as Lingala, Swahili, and Kirundi.

The group was considerably heterogeneous, both regarding their previous training ranging from university graduates (some in Translation, Medicine or related fields) to people who had not finished secondary school- and in terms of their level of French — ranging from native and near-native speakers, to trainees with a low level of proficiency in the language. Their level of involvement in the training programme was also rather diverse-ranging from genuinely involved trainees, eager to get the most out of the training programme, to trainees who made the minimal effort, limiting themselves to attend.

\subsubsection{Description of the training sessions}

At the beginning of each session, a contextualising activity or scenario was proposed to encourage reflection among trainees. During this first part, different topics emerged and were theoretically discussed by the trainer. The contents were inductively presented throughout the training programme, progressively increasing the complexity of the tasks.

A model session of this training programme would include lessons of the different modules composing it and their contents would be structured as follows:

1. review of the previously seen contents,

2. role plays,

3. theoretical input and debate, and

4. practical activities.

The in-class time was complemented by 32 hours of compulsory guided internships at the BICN. These internships gave trainees the opportunity to apply the knowledge acquired during the on-site lessons in real situations. Trainees were asked to share the challenges they encountered in their internships during the week in an online forum created for this module (Module 3. Critical thinking on ethics and guided practice). Later on, these situations were discussed during in-person debates in the lessons, with the aim of stimulating trainees' analysis 
and critical thinking, in search of a consensual way of solving the different proposed situations, in accordance with the course's theoretical contents.

\subsection{PSI basic training programme evaluation}

After delivering the training, the study of its impact was conducted. To this end, two focus groups were held, allowing the collection of data on trainees' experiences. The information collected was subjected to content analysis and contrasted with the information provided in an action-research report, which included the trainer/researcher's teaching experience.

\subsubsection{Focus groups}

Two focus groups were conducted following a semi-structured script, which was applied flexibly by a moderator, according to the evolution of each meeting —adding or removing questions, as required by the situation.

The script consisted of the following seven open-ended questions aiming to collect data on trainees' experience throughout the training programme and the difference that it had brought to both their PSI practice:

1. How do you feel about the training programme?

2. Could you describe what you appreciated about the training programme?

3. Were you able to put what you learned into practice?

4. Did the training programme make a difference in your practice?

5. In your opinion, how could this training programme be improved?

6. Do you feel that this training programme helped you obtain a higher professional recognition from healthcare providers?

7. Do you feel that this training programme helped you obtain a higher professional recognition from users?

Each of these focus groups was audio-recorded, then transcribed verbatim. While all trainee interpreters were invited to participate in the focus groups, a total of 11 of the 23 interpreters who passed the training programme came to share their experiences in either of the two focus group sessions.

\subsubsection{Action-research report}

The trainer/researcher's observations were collected in a 17-page action-research report which, after contextualising the training programme and its design, deals with training-related issues such as the conditions of admission of trainees, the description of the training programme (objectives, pedagogical approach, teaching materials), the description of the group of trainees (working languages, levels of education, attitudes towards learning), the training content, the guided practical work undertaken during internships, the evaluation system and other outstanding considerations registered on a logbook.

\subsubsection{Data analysis}

First, focus groups transcripts were read carefully, while taking note of relevant addressed aspects of the training experience. Then, a content analysis was applied to the collected data, which consisted of systematically identifying, coding and grouping contents in an information reduction process. Following the methodology designed for previous research (BurdeusDomingo, 2010), data was coded using discursive tables (Farías and Montero, 2005), which allowed extracting the main topics discussed (i.e. the categories of our study), as well as to compress data and store it efficiently. The categories of the study were then hierarchically organised in the form of a conceptual map (Burdeus-Domingo, 2010; Burdeus-Domingo and 
Arumí, 2012), facilitating the compilation of the information shared by participants all through the focus group sessions, and allowing for description of their contents (i.e. result extraction).

\section{Results}

\subsection{Focus groups results}

Trainees appeared generally fulfilled with the training programme. They appreciated the opportunity to meet and share experiences with fellow BICN interpreters. They were also pleased to have been introduced to the different ethical aspects, which fostered their feeling of confidence when making ethical decisions, although there were often points of friction between the content of PSI ethical codes and their altruistic desire to help others. Furthermore, they valued having been trained on interpreting techniques and strategies - although they did not always agree on the need to apply them systematically. Overall, they stated that the transfer into their everyday practice of the contents of the training programme helped them to gain confidence when interpreting, providing them a feeling of control in their practice as public service interpreters. Willing to improve their practice, they suggested the convenience to add even more interpreting practice and ethical debates, although these two activities were the main focus of the programme and covered most of the on-site lessons time. Finally, they stressed the difficulty of the final interpreting evaluation test - generally considered too high. However, all trainees felt that the programme had helped them to become more professional and they considered that this was perceived by both healthcare practitioners and users.

\subsection{The action-research report}

The trainer/researcher's final report outlines the difficulties associated with teaching the course, relating them firstly to the assignment issued by the BICN and ultimately to the demographic characteristics of the City of Québec.

The document reveals that the selection process undertaken by the BICN had not been strict enough, driven by a desire to universalise PSI services and to have the widest range of languages possible. This resulted in the selection of potential interpreters who often lacked certain transversal skills that are essential for PSI practice (e.g. French language command, information sequencing or organisation skills, etc.), which added an obstacle to the teachinglearning process. Beyond the difficulties imposed by the heterogeneity of the group in terms of their previous training — revealing the lack of learning skills of some trainees-, the low level of command of the French language of some trainees was a clear obstacle to PSI training. Such heterogeneity led to the natural creation of two subgroups of trainees, who progressed through the course at different speeds. Provided the BICN's laxity in respecting the agreed premises for the configuration of the group of trainees - which included the need for an advanced level of French language, as well as including at least three trainees per language combination, so that the application of the special regime methodology was possible-, the decision was taken to decrease (although not eliminate) the percentage of code-switching activities. Therefore, the number of pre-interpreting activities - mental agility activities, concentration and attention division activities, memory activities, note-taking activities, paraphrasing activities, etc. - was higher than initially planned. Likewise, those trainees who did not share language pairs with any other trainee had to work from French into French during interpreting activities.

In some cases, trainees' preconceived ideas, as well as the malpractice habits they had been acquiring throughout their experience as untrained BICN interpreters, hindered the acquisition of knowledge, since trainees often questioned certain content — ranging from 
certain ethical aspects to procedural aspects of PSI. Some trainees defended PSI more as an altruistic activity, focused on helping others - immigrants with similar problems to those that trainees had personally experienced in the past—, than as a professional activity, framed by a code of ethics and with particular limited functions. Likewise, they considered interpreting techniques and strategies - i.e. interpreting complete interventions of healthcare conversations with the help, if necessary, of notes - to be unrealistic, showing themselves resistant to change, by claiming that PSI practice consisted of the restitution of short segments of interlocutors' interventions - regardless of whether they contained complete ideas or not-, since this is what they had been doing so far.

Trainees' motivation towards the course also had an undeniable effect on the teachinglearning process. By paying attention to their behaviours in the classroom, two groups of trainees, in terms of motivation, were perceived. There was a first group of unmotivated trainees who followed the training as an obligation, instigated by the BICN. Paradoxically, they expected a certificate recognising progress in their professional quality and, at the same time, were uninterested in interiorising the changes to achieve it. On the other hand, there was a second group of highly motivated trainees. These would have freely chosen to follow the training programme, either for their personal development or to acquire additional professional skills. The report discloses that it was much easier to train this latter group, given their willingness to participate in training activities, with contributions that were relevant for their own learning as well as for that one of their fellow trainees'. Such contributions transferred both knowledge and experiences that led to a synergy in the acquisition of knowledge in the classroom.

Finally, the report reveals that the presence of the BICN's representatives (the trainees' employer) in the on-site training sessions had an impact on the teaching-learning process. This is due to the fact that, in their eagerness to defend the status quo of the activity carried out so far by the BICN, they (probably unconsciously) justified unadvisable practices during on-site lessons, forgetting that a change in trainees' PSI practice was needed to contribute to both the optimisation of the services provided to allophone users and the professionalisation of PSI. Such unexpected situation led some trainees to mistrust the contents of the course, to the benefit of what was promoted by their direct employer.

All of the above led to a generalised underperformance, as shown in Figure 1:

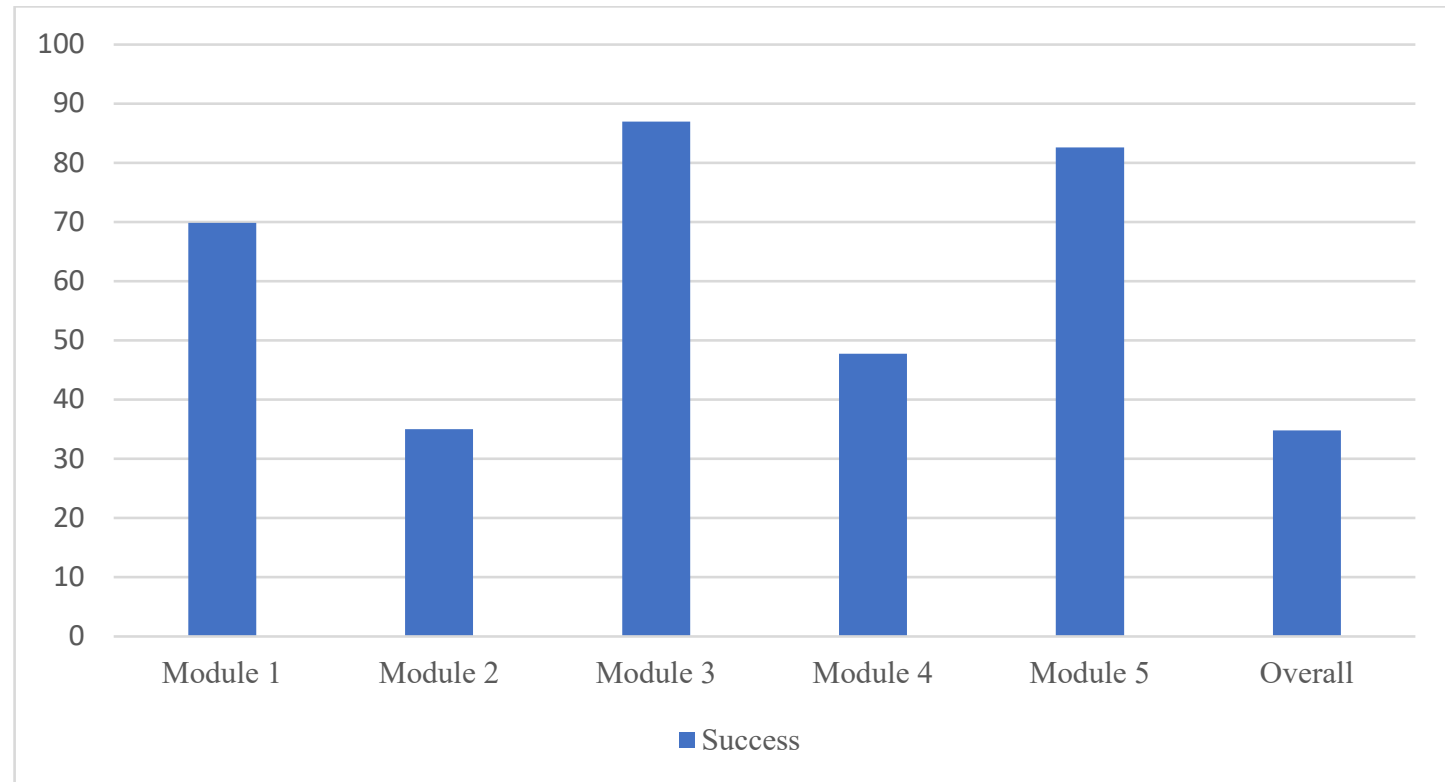

Figure 1. Results of the PSI basic training programme's summative evaluations. Source: Own elaboration. 
This figure shows the results of each module's summative evaluations, as well as the overall final results. It shows that, with $87 \%$ passing, Module 3 (Critical thinking on ethics and guided practice) had the best results $(\mathrm{n}=20)$. This was indeed the module that attracted the greatest interest among trainees - despite the differences of opinion. Next, there is Module 5 (Immigration, culture and healthcare system), with a success rate of $82.6 \%(\mathrm{n}=19)$, followed by Module 1 (Introduction to PSI and intercultural communication), laying the theoretical foundations of PSI, with a $69.9 \%$ pass rate $(n=16)$. Despite the interest that it generated among trainees, Module 4 (Tools and resources: terminology and documentation for healthcare interpreters) got poor results, with a low $47.8 \%$ success rate $(n=11)$. However, the module with the lowest results - 34.8\% success rate, which represents 8 out of 23 - was the one aiming to develop interpreting techniques and strategies (Module 2, Initiation to interpreting techniques). This result is directly linked to the lack of acceptance of the need for a change in the way PSI is practised within the BICN. As a result, the final scores were quite low, with an overall success of $34.8 \%(n=8)$.

\section{Conclusions}

This study has corroborated the need for training of the non-professional interpreters working for the BICN. The positive comments shared all through the focus group sessions indicate that trainee interpreters are very satisfied with the training, as the whole experience made them feel more professional, which instigated their urge for further training. Nonetheless, these results must be seen in light of the intrinsic limitations of the chosen approach. First, there is a possible tendency for socially acceptable arguments to emerge in focus group discussions. Second, there is a potential predisposition for a certain type of participant - motivated trainees - to dominate the research process. All things considered, the study confirmed that some training is indeed necessary to enable BICN's non-professional interpreters to offer quality PSI services, capable of providing healthcare conversations' interlocutors with the communicative autonomy they need to ensure the respect of allophone users' rights. In this sense, we agree with Sasso and Malli (2014) about the convenience of clearly defining the process of training to adopt in Canada — or at least within the province of Quebec - in order to progressively advance towards the professionalisation of PSI.

The main objectives of the project were achieved: despite the low success rates, the proposed programme has contributed to the training of BICN interpreters. It respected the initial premises, as it was adapted to the participation of all types of trainees - regardless of their level of education and language combination-, thus allowing us to respond to the linguistic needs of the immigrant population of the City of Québec - knowing that they vary over time.

The applied pedagogical approach was adapted to the BICN's request, since it allowed all types of trainees - from those most used to learning, to those who presented the most remarkable difficulties in the teaching-learning process - to develop the necessary skills for PSI. This was possible thanks to the promotion of:

- reflexive and collaborative contextualised learning, based on trainees' own experience, which allowed them to experience training contents in the first person (through the resolution of PSI problems);

- learning as a social activity: trainees helped each other move forward as a group, reinforcing the needs of those less used to learning. This fostered trust amongst them and led to a continuous learning exchange, which was highlighted as one of the most appreciated points. Such exchange is likely to be extended over time, enhancing natural (yet unconscious) continuous learning bonds; 
- significant learning: the proposed training activities developed trainees' capacity to continue acquiring knowledge autonomously, by introducing them to the analytical procedures that will foster reflection on their work as BICN interpreters; and

- active learning, which allowed for the acquisition of knowledge from practice, with the help of spontaneous feedback from the trainer and fellow trainees.

Although the application to PSI of ESIT's special regime teaching methodology was one of the main challenges of this project, this experience has confirmed that it is not only possible, but advisable, since its application allows responding to PSI services' language needs. It makes it possible to (1) train groups of interpreters of several language combinations, and (2) train interpreters working with the most requested languages at any given time, as it is not a sine qua non requirement for trainers to share working languages with trainees. This was a double challenge, since, beyond what it means - in terms of contents - to apply this methodology to PSI (for healthcare and social services), novel interpreters had to be trained, most of whom were unfamiliar with the field of Translation and Interpreting. Moreover, they often lacked study habits, which constituted an added challenge of its own. Therefore, after getting to know the group of trainees, as well as their previous experiences and limitations - such as a slightly generalised lack of command of the teaching language-, it was considered appropriate to work only in French at an early stage, leaving code-switching activities for the more advanced stages of the training programme.

The results of this study underline the importance that trainee motivation has for the integration of knowledge. As observed, such motivation can be conditioned both by (1) the difficulties involved in the re-learning process and (2) the influence of PSI recruiting entities - aspects that, in this case, were strongly related. These factors pose additional barriers to the training of non-professional interpreters in PSI, as opposed to training Translation and Interpreting students.

Our training programme took trainees' preconceptions about PSI — acquired throughout their experience as untrained interpreters for the BICN — as its starting point for knowledge development. However, this experience has confirmed that, as OCDE (2001) points out, for knowledge to be developed and interiorised, an interest in new learning must be found, so that trainees get to restructure their ideas and relate new knowledge to their previous experiences. The resistance to change observed in certain trainees and unconsciously supported by the BICN representatives - by pretending to participate in classroom training activities - , had a demotivating effect in some trainees. Having trainees hearing their direct employer justify the practices carried out so far considerably hindered the PSI training process.

All things considered, this research-action study on PSI training for non-professional longserving interpreters corroborates that, as several authors previously stated, the image public service interpreters have of their own profession is conditioned by the vision that their recruiting entity has of it (Vargas-Urpí, 2013; Leanza, 2017). This confirms that, as revealed by Vargas-Urpí (2013), recruiting entities exercise their influence on PSI services through training actions. This occurs, as suggested by various authors, because of the desire of such entities to defend their own interests (Salaets, 2012; Vargas-Urpí, 2013), which, while are often of a financial nature - with the intention of obtaining PSI services at a low cost-, also encompass other interests, such as the desire to have a large number of trained interpreters even if training actions do not change their practices. It can be inferred that, while involving contracting entities is interesting when it comes to setting training objectives, promoting training, etc., training actions should be separated from them in order to avoid inferences that would hinder the transfer of knowledge. This is only possible with the involvement of academic institutions.

In order to overcome the barriers that, according to this experience, add up to PSI training when trainees are non-professional longserving interpreters, we suggest incorporating: 
- a selection process considering the motivation of potential interpreters;

- contents - or even modules, which could be optional, depending on trainees' needsto work on the transversal skills needed for interpreting which, a priori, should be mastered when accessing PSI training -i.e. oral discourse analysis skills, discourse structuring skills, oral expression skills, reinforcement of the non-native language, speciality language, diction and phonetics...- ;

- individualised tutoring sessions, in which each trainee can establish —with their trainer's help - their own set of learning objectives according to their needs, as well as concrete guidelines for achieving them; and

- training programmes divided into different stages or levels, so that trainees can only accept PSI assignments of a given complexity, according to their levels of expertise in PSI.

\section{Acknowledgements}

This project would not have been possible without the participation of the Banque d'Interprètes de la Capitale Nationale. We thank them sincerely. Author contributions: YL and NBD were responsible for the study conception and design. NBD undertook the literature review, conceived and delivered the training programme. SG provided insight on training content related to Quebec's healthcare system. SP instructed the trainer on ÉSIT's special regime methodology. NBD wrote the action-research rapport, performed the data analysis and drafted the paper. SG, SP and YL revised the paper. YL supervised the study.

\section{References}

Abril Martí, M. I. (2006). La interpretacion en los Servicios Públicos: Caracterizción como Género, Contextualización y Modelos de Formacion. Hacia unas Bases para el Diseño Curricular. [Doctoral dissertation, University of Granada].

Abril Martí, M. I. \& Martin, A. (2008). Profesionalizar en la práctica: la competencia en interpretación en los servicios públicos como base para la formación de profesionales. In C. Valero-Garcés (Ed.), Investigación y Práctica en Traducción e Interpretación en los Servicios Públicos DESAFÍOS Y ALIANZAS (pp. 103-120). Universidad de Alcalá.

Auger, V. (2005). La communication interculturelle et ses obstacles. Interactions, 9(1), 123 159.

Boéri, J. \& de Manuel Jerez, J. (2011). From Training Skilled Conference Interpreters to Educating Reflective Citizens. The Interpreter and Translator Trainer, 5(1), 41-64.

Burdeus-Domingo, N. (2010). Interpretación en los servicios públicos en el ámbito sanitario en la provincia de Barcelona. [Master's tesis, Universitat Autònoma de Barcelona].

Burdeus-Domingo, N. (2015). Interpretación en los servicios públicos en el ámbito sanitario. Estudio comparativo de las ciudades de Barcelona y Montreal. [Doctoral dissertation, Universitat Autònoma de Barcelona].

Burdeus-Domingo, N. (2019). Structuring Public Service Interpreting: the Interpreters Bank Model as an Organised Response to Communication Needs. FITISPos International Journal, 6, 46-61.

Burdeus-Domingo, N. \& Arumí, M. (2012). Estudio de la práctica de la interpretación en los servicios públicos en el ámbito sanitario en el área metropolitana de Barcelona. Sendebar, 23, 17-36.

Centre Intégré Universitaire De Santé et de Services Sociaux de la Capitale-Nationale. (2019). Portrait de santé 2019 de la population de la Capitale-Nationale. Structure de la 
population.

https://www.ciussscapitalenationale.gouv.qc.ca/sites/default/files/docs/fas_structure de la population 2 019-06-07.pdf

Détienne, S. (2011). Le rémime spécial de 1'ESIT. Translittérature, 40, 54-57.

Elliot, J. (2000). La investigación-acción en educación. (4 ${ }^{\text {th }}$ ed.). Morata.

Farias, L. \& Montero, M. (2005). De la transcripción y otros aspectos artesanales de la investigación cualitativa. International Journal of Qualitative Methods, 4(1), 1-14.

Gredler, M.E. (1997). Learning and instruction: Theory into practice. ( $3^{\text {rd }}$ ed.). Prentice Hall. Hale, S. (2007). Community Interpreting. ( $1^{\text {st }}$ ed.). Palgrave Macmillan.

Hanna, S. (2009). Exploring MA students' attitudes to translation theory and practice : an action-research approach. The Sign Language Translator and Interpreter, 3(2), 141155.

Haro-Soler, M. M. \& Kiraly, D. (2019). Exploring self-efficacy beliefs in symbiotic collaboration with students: an action research project. The Interpreter and Translator Trainer, 13(3), 255-270

Healthcare Interpretation Network. (2007). National Standard Guide for Community Interpreting Services. $\quad$ https://accessalliance.ca/wpcontent/uploads/2015/03/NationalStandardGuideForCommunityInterpretingServices.p $\underline{\mathrm{df}}$

Hubscher-Davidson, S. (2008). A Reflection on Action Research Processes in Translator Training. The Interpreter and Translator Trainer, 2(1), 75-92.

Industry Canada. (2007). Community interpreting in Canada. http://www.ic.gc.ca/epic/site/lain-inla.nsf/en/h_qs00229e.html

Jiménez-Salcedo, J. (2010). Traducción-Interpretación en los servicios públicos en Quebec: un modelo para Andalucía. https://www.centrodeestudiosandaluces.es/datos/factoriaideas/IF002 10.pdf

Jiménez-Salcedo, J. (2014). Politiques linguistiques et interprétation en milieu social au Canada : des droits linguistiques aux droits d'accès aux services publics. Cédille Revista de Estudios Franceses, Monografias, 4, 131-147.

Kelly, D. (2005). A Handbook for Translator Trainers. A Guide to Reflective Practice. St Jerome Publishing.

Leanza, Y. (2017). Faire entrer le plurilinguisme dans les équipes cliniques. Analyse contextuelle du travail avec interprète. L'Autre, 18(3), 272-281.

Leanza, Y., Boivin, I. \& Rosenberg, E. (2010). Interruptions and resistance: a comparison of medical consultations with trained and family interpreters. Social Science and Medicine, 70(12), 1888-1895.

Leanza, Y.; Brisset, C.; Rocque, R. \& Boilard, A. (2017). Challenges to and recommendations for working with a community interpreter in mental health. A Canadian perspective. In E. Jacobs \& L. Diamons (Eds.), Providing Health Care in the Context of Language Barriers: International Perspectives (56-70). Multilingual Matters.

Lewin, K. (1944). The dynamics of group action. Educational Leaderchip, 1(4), 195-200.

Mikkelson, H. (2014). Evolution of Public Service Interpreter Training in the U.S. Public Service Interpreting \& Translation, 1(1), 9-22.

Organisation de coopération et de développement économiques (2001). Pédagogie et apprentissage des adultes - État des lieux et recommandations. http://www.oecd.org/fr/education/innovation-education/1831501.pdf

Ozolins, U. (2000). Communication Needs \& Interpreting in Multilingual Settings: the International Spectrum of Response. In R. P. Roberts, S. E. Carr, D. Abraham \& A. Dufour (Eds.). The Critical Link 2: Interpreters in the Community : Selected Papers 
from the Second International Conference on Interpreting in Legal, Health, and Social Service Settings ( 21-33). John Benjamins Publishing Co.

Pöchhacker, F. (2004). Introducing Interpreting Studies. Routledge.

Risku H. (2016). Situated learning in translation research training: academic research as a reflection of practice. The Interpreter and translator trainer, 10(1), 12-28.

Rodríguez de Céspedes, B. (2020). Beyond the margins of academic education: identifying translation industry training practices through action research. Translation \& Interpreting, 12(1), 115-126.

Roux-Faucard, G. (2005). Une didactique de la traduction à partir des langues périphériques : le « régime spécial » à l’ÉSIT. Meta, 50(1), 194-209.

Salaets, H. (2012). The next step in the CBI professionalisation process: training the public services providers. The Interpreters Newsletter, 17, 191-203.

Sasso, A. \& Malli, K. (2014). Trying to fit a square peg in a round hole: Is community interpreting just too big for public policy? The Canadian experience a provocation. FITISPos International Journal, 1(1), 42-50.

Takeda, K. (2010). What interpreting teachers can learn from students: A case of study. Translation \& Interpreting, 2(1), 38-47.

Valero-Garcés, C. (2003). Una visión general de la evolución de la traducción e interpretación en los servicios públicos. In C. Valero-Garcés (Ed.). Traducción e interpretación en los servicios públicos. Contextualización, actualidad y futuro (pp. 3-35). Comares.

Vargas-Urpí, M. (2013). El papel de las entidades contratantes en la interpretación en los servicios públicos: ejemplos del contexto catalán. Sendebar, 15, 43-72.

\section{Date of reception/Fecha de recepción: $30 / 10 / 2020$ \\ Date of acceptance/Fecha de aceptación: 30/11/2020}

How to cite this article?/ ¿Cómo citar este artículo?

Burdeus-Domingo, N., Gagnon, S., Pointurier, S., \& Leanza, Y. (2021). Bridges and Barriers in Public Service Interpreting Training: Instructing non-professional Longserving Interpreters. FITISPos-International Journal, $8(1)$ $28-42$. https://doi.org/10.37536/FITISPos-IJ.2021.8.1.267 